\title{
Hakim Imad al-Din Mahmud ibn-Mas'ud Shirazi (1515-1592 A.D.), a Physician and Social Pathologist of Safavid Era
}

\author{
Seyyed Alireza Golshani ${ }^{1,2}$, Behnam Dalfardi ${ }^{2,3}$, Ezzat al-Sadat Motahari ${ }^{1}$, Mehdi Dehghan Hesampour ${ }^{1}$, \\ Mahsa Ansari ${ }^{1}$, Hassan Yarmohammadi ${ }^{2,3}$ 圧
}

${ }^{1}$ Department of History, Faculty of Literature and Humanities, Shiraz University, Shiraz, Iran.

${ }^{2}$ Research Office for the History of Persian Medicine, Shiraz University of Medical Sciences, Shiraz, Iran

${ }^{3}$ Student Research Committee, Shiraz University of Medical Sciences, Shiraz, Iran

\begin{abstract}
The Safavid era (1501-1736 A.D.) was the threshold of spreading security and welfare in the Iranian society. This era provided the chance for the talents to set steps for advancement. One of the characters in the history of Persian medicine who achieved successes in the shadow of the existing peace and security during the Safavid Empire was Hakim Imad al-Din Mahmud Shirazi. While he was ministered in the court of Shah Tahmasb Safavi (King Tahmasb), he enjoyed the patronage of Dar al-Shifa Razavi (Razavi health care service) in Mashhad. He managed to leave a legacy of valuable essay and complications resulting from the abundant experiences he gained through the journey to India. The present paper is a study about Hakim Imad al-Din's life and his essays.[GMJ. 2013;2(4):169-73]
\end{abstract}

Keywords: Imad al-Din Mahmud Shirazi; India; Imam-Reza Hospital; Safavid; Shiraz

\section{Introduction}

Tn the end of Medieval period, Savafid dyInasty (1501-1736 A.D.) was founded by Shah Esmaeil-e Safavi (King Esmaeil). It was an important and influential Empire in the Middle-East and was accompanied by significant scientific changes. Art and architecture reached their zenith of prosperity and economy also flourished in the shadow of safety in this period. Nonetheless, the medical sciences gained lower achievements compared to the previous periods. Of course, it does not mean that scholars took no positive steps in the progress of medicine; rather, compared to the later period, renowned physicians appeared and conducted corrective actions regarding

\section{GMJ}

2013 Galen Medical Journal

Fax: +98 7312227091

PO Box 7461686688

Email:info@gmj.ir medical issues in Qazvin and Isfahan (two Safavid capitals located in the center of Iran)[1]. The present paper aims to review Hakim Imad al-Din Mahmud Shirazi's biography and his most significant remained works. We tried to take a look at the changes in the Safavid period and understand the reasons for writing essays on opium and syphilis by Imad in that era.

\section{Hakim Imad al-Din Mahmud ibn-Mas'ud Shirazi:}

Hakim Imad al-Din Mahmud ibn-Mas'ud Shirazi (1515-1592 A.D.) was a physician, known as Imad, and was born in Shiraz in 1515 A.D. (921 A.H.). He lived during the end of Shah Tahmasb (King Tahmasb) and the beginning

\footnotetext{
Correspondence to:

Address Correspondence to Hassan Yarmohammadi, MD; Student Research Committee, Shiraz University

of Medical Sciences, Shiraz, Iran

Telephone Number: +989173365275

Email Address: Yarmohammadihassan@yahoo.com
} 
of Shah Abbas (King Abbas) governments [2]. Imad al-Din's father, Hakim Mas'ud ibnMas'ud Shirazi, was a physician. In days of youth, his father trained him as a physician and then, he worked for Amir Abdullah Khan Astajlu, Shirvan's (today located in Azerbaijan Republic) ruler [3]. However, he lost his reputation and the ruler's trust due to various reasons. Because of his mistake, the ruler caught him in very cold pool during the night but he could save his life by eating a lot of opium [4]. After that, he suffered from addiction and palsy; therefore, he wanted to know this social disease and succeeded in writing the first essay on opium, entitled "Resaleh Ophioun" (The Book Of Opium). In this book, Imad al-Din discussed about the nature, chemical properties, advantages, and disadvantages of opiates [2]. Then, he worked for King Tahmasb and wrote a book in the field of medications and drug combinations in Arabic language entitled "al-Morakkabat al-Shahieh" (Royal Vegetables) containing an introduction, 25 chapters, and 108 pages [3].

King Tahmasb gave him the responsibility of Imam-Reza's hospital in Mashhad when he was aware of his intelligence and knowledge. The aim of establishing that hospital was providing care for the pilgrims. He said that he wrote a book on syphilis, entitled "Resaleh Atashak" (The Book of Atashak) when he had free time $[4,5]$.

The story of his journey to India was true but we could not certainly say whether he wrote the book before or after this journey because in the introduction of "The Way of Eating Ginseng and Its Benefits", it seems that he had spent twenty years in India [3].

His most important works on medicine and pharmacology are listed below: "Resaleh Phadzahr" (The Book Of Antidote) was written in Persian language. He divided this essay into two parts, animal and mineral, and mentioned how to use or drink antidote according to his personal experiences. This manuscript could be considered as the first remained writing about antidote in Persian language [6]. "Bikh-e Chini" or "Choob-e Chini" (Essay on Ginseng) was written in Persian language in 947 A.H./1540 A.D. In this essay, he discussed about the advantages of ginseng for quitting addiction to opiate and treatment of syphilis. In "Jedri" (jedri means a small pox appearing in children's face) which was written in Persian, he discussed about how to wipe out the signs and symptoms of chicken pox. In "Atrilal", he discussed about the nature of all types of medications and how to use them. He wrote "Amraz Sebyan" in Persian and discussed about infant and childhood illnesses. In "Ozan and Makayel", he discussed about how to use medications. "Imad al-Din's Experiences" in Persian language was a short essay with five and a half pages. By reading this book, we could realize that he gained his experiences by reading the Indian scholars', Avicenna's (980-1037 A.D.), and other professors' books and could write this valuable essay. Another work of Imad al-Din which is not related to the field of medicine was about the mineral stones. "Ruby" was a short article about the properties and composition of Ruby. $\mathrm{He}$ also wrote an article on Iranian new year which shows his attention to the traditions [7, 8].

In addition to the manuscripts mentioned above, he has other medical works in Arabic language, as well: "Anatomy Description From al-Qanun" in Arabic language included the description of some parts of Avicenna's Canon book. Imad al-Din was one of the analysts of Avicenna's Canon book who chose the anatomy section of this book and also added up his own description to this part which was more detailed and complete compared to Avicenna's book. "Sharh-e Qanuncheh" (Description of Qanuncheh) which was written by Mahmud ibn-Umar al-Chaghmini (745 A.H./ 1344 A.D.) in Arabic language and was a basic course in the field of medicine and had several parts. One of these parts dealt with the description of Imad al-Din's Qanuncheh [9]. Imad al-Din Shirazi's family was considered as great doctors in Iran and his son was also a scholar. Mohammad Bagher was an ophthalmologist in the court of king Abbas (15871629). Mistakenly, Cyril Elgood (1893-1970) (British physician and historian of medicine in Persia) said that Imad al-Din was Mohammad's son, whereas he himself has said in his book that Mohammad was his son. His son wrote a book entitled "Mature and Elegant" 
about eye diseases in 1602 which was consisted of two parts. The first part was about the treatment of eye diseases, while the second one was about an ointment for eyes. He also wrote a book entitled "Fi Moshel" (In Laxatives) in Arabic language about laxative medications and how to use them. This book included twelve chapters [9].

His nephew was also a doctor and a writer. Pharmaceutics is one of the central topics in traditional medicine. In a book on pharmaceutics, we could obtain useful information about Imad al-Din, but the author's name was unknown. The book indicated that his nephew was his student and Kamal al-Din Hossein Shirazi was his professor. Unfortunately, we have no clear information about Imad al-Din's death. Seyyed Zol al-Rahman, professor of traditional medicine in Islamic university and the founder of the Avicenna Academy in Aligarh, India, said that Imad al-Din died in 1000 A.H. / 1592 A.D. In addition, Saheb Kholdebarin said that he died in Razavi holy shrine in Mashhad $[9,10]$.

\section{Hakim Imad al-Din and his Essay on Opi- um Addiction}

One of the vexing problems of the Iranian society in the sixteenth century which is concurrent with the beginning of the Safavid era and the life of Imad al-Din Mahmud Shirazi was excessive consumption of opium.

One of the Iranian customs was consuming opium. They made a small pill of opium about the size of a pea and swallowed it. Opium addicts could eat opium because they wanted to be euphoric. Herbalists also had lots of profit because of selling opium [11]. Tavernier (1605 - July 1689) (a French diamond merchant and traveler) wrote about the outbreak of this social disease: "Young Iranian men and women had the habit of smoking tobacco. They had smoked tobacco so much that they felt euphoric. The first thing that they prepared to break their fast during the Ramadan was Hookah. They knew about its disadvantages, but they could not give up opium. The source of opium is opium poppy and only the pod portion of the plant can produce opium. Opium addicts admitted that opium was harmful, but they said that it was their habit. When they did not take opium, they had a pale yellow face and were always weak and sleepy. They needed greater and greater doses of the substance to achieve the same original effect. The effects of a dose of opium last for about four hours. Then, the body rebounds with a set of withdrawal symptoms; the symptoms include watery eyes, muscle pain, anxiety, agitation, nausea, and insomnia" [12].

They also drank "Kuknar" (poppy seeds). They went to special houses with their friends and did risible movements. Before drinking, they insulted each other, but they made peace and told tales and stories afterwards [12] Tavernier also wrote about taking other drugs: "The other thing which is also bitter and distasteful is named Hashish which consists of the dried flowers of cannabis plants and is stronger than all the other beverages. Therefore, Islam has forbidden Hashish, but opium is not forbidden. It was so hard to find someone who did not use to smoke or drink. Iranians also indulged in drinking alcohol meanwhile it was forbidden in Islam; they said that we must be tosspot to get rid of sadness and endure the hardship of life" [12].

The main causes of addiction in the Safavid court were social intercourse with Europe, establishment of friendly relationships with India and Ottoman, sending commercial transactions to Iran, giving presents to kings, and beginning of war between Ottoman and Iran and Turkish addicted soldiers [13].

Initially, the dignitaries and affluent classes of the society were addicted [14]. Gradually, Safavid rulers gave opium to their children as a fun. Rulers wanted to ensure that their children did not want to be their successors [12]. Jean Chardin (1643-1713) (a French jeweler and traveler) wrote about the outbreak of addiction in various classes of the society: "At first, consumption of opium was common among the dignitaries and it gradually became common among the various classes of the society [11]. "They had beautiful boxes to put opium in" $[15,16]$.

When a European tourist visited Iran, he said that pubs were crowded and the people in Isfahan went there every day to have fun. $\mathrm{He}$ also said that it was ignominious for Iranian people [14]. 
One of the main reasons of Imad al-Din for writing "Opium" was this social disease and he thought that it was necessary to write about it.

\section{Writings about syphilis}

Syphilis is a sexually transmitted infection. It was carried to Europe by the crewmen returning from Christopher Columbus's (14511506) (an Italian explorer and navigator) voyage to Americas. In seven years, one out of every three individuals was infected and five million out of sixteen million people died. The outbreak of syphilis among tribes and families made the inhabitants of the city anxious and threatened their lives [17]. Before 1569, no books were written about syphilis and Imad al-Din was the first person who wrote a book on this issue. He said: "No one wrote a book about syphilis. Just Bahā'al-Dawlah Nūrbakhshī Razi referred to this disease in his book entitled 'Khulāṣat al-Tajārib' (The Summary of Experience) (written in 907 A.H. / 1501 A.D.) [18].

On the whole, we could say that the people were worried about the situation. Sir John Chardin (1643-1713) in his book said: "Syphilis was epidemic in Iran. The patients did not try to cure themselves. The individuals who suffered from syphilis in Europe oppressed great pain because of the good local weather. However, the weather is dry and clean in Iran; therefore, the patients could tolerate their pain and the disease did not become severe because they went to the bathroom a lot" [19].

Of course, it does not imply the insignificant impact of the disease. Syphilis also penetrated into the Safavid court. Abdul Hossein Navai said: "Shah Abbas II was an efficient ruler, but he loved drinking alcohol and insisted on sleeping with a woman who had syphilis when he was drunk. He was infected with syphilis and died" [20].

Qasidin Mansure Dashtaki Shirazi in "Khulāṣat al-Tawarikh" (Summaries of History) said: "I was obsessed about my health and I did not go anywhere. When I met people, I did not exchange kisses or shake hands." Although this disease in Iran was not as dangerous as in Europe, Imad al-Din wanted to write about it in the "Syphilis" book [21].

\section{Conclusion}

By Safavid Empire and King Tahmasb coming to power, the social situation was great in the tenth century and culminated at the time of King Abbas. We could say that Iran reached political stability at that time. In this situation, one of the doctors who worked in the field of medicine and had valuable books was Imad al-Din Shirazi. King Tahmasb gave him the authority to manage the only hospital in Iran which was in Mashhad. He wrote essays about "Opium" and "Syphilis" and discussed about the spread of opium addiction and syphilis. Imad al-Din successfully wrote the first essay on opium. His works influenced medical sciences in both Iran and India.

\section{Acknowledgements}

Research Improvement Center of Shiraz University of Medical Sciences, Shiraz, Iran and Ms. A. Keivanshekouh are appreciated for improving the use of English in the manuscript.

\section{Conflicts of interest}

No conflict.

\section{References}

1. Zanuri Tabrizi AH. Matrah-al-Anzar fi Trajeme Atebba' al-Asar Falsof va Falasefeh al-Amsar. In: Mohaddes MH, editors. Tehran: Sina Cultural and Legal Institute, Shahid Beheshti University of Medical Sciences and Health Services; 2004, p 266. [In Persian]
2. Elgood CL. Medical history of Persia and the eastern caliphate. Translated by Forghani B. Tehran: Amir Kabir; 2007, p 431. [In Persian]

3. Safa Z. History of literature in Iran. 8th ed. Tehran: Ferdows; 2000. p 362. [In Persian] 
4. Torkaman S. The History of Alam Aray Abbasi. Correction by Afshar I. 3rd ed. Tehran: Amir Kabir; 2003, p 168. [In Persian]

5. Elgood CL. Medicine in Safavid period. Translated by Javidan M. Tehran: Tehran University Publication; 1978. p 431. [In Persian]

6. Elgood CL. A medical history of Persia. Cambridge: Cambridge University Press; 1951. p 371.

7. Kiani H, Nimrouzi M, Parsaei M. Introduction of an Outstanding Scientist of Iranian and Islamic Traditional Medicine: Emadodin Mahmoud-Ibn Masoud Shirazi. Journal of Islamic and Iranian Traditional Medicine. 2011;2(3):249-54. [In Persian]

8. Mir MT. Pars famous physicians. Shiraz: Shiraz University Press; 1984. p 127. [In Persian]

9. Zol-alrhman HS. Emad-Aldin Mahmoud Shirazi and Works. Translated by Abbas SH. Journal of Ghandeparsi. 2004;27:14960. [In Persian]

10. Vale Qazwini Esfahani MY. Kholdebarin. Researcher and editor by Muhaddith $\mathrm{MH}$. Tehran: Publication of Dr. Mahmoud Afshar Foundation Endowment; 1993. p 455. [In Persian]

11. Olearius A. Moskowitsche and persische Reise $\square$. Translated by $\square$ Behpoor

A. Tehran: Publishing and Cultural Organization Initiative; 1984. pp 272-3. [In Persian]

12. Tavernier JB. Voyages en Perse. Translated by Noori A. Tehran: Sanai Libraries and Bookstores Tayed Publication; 1984. p 639-40. [In Persian]
13. Kohi Kermani H. History of opium and opium addicts in Iran. Tehran: Elmi Publication; 1945. p 117. [In Persian]

14. Chardin J. Journal du voyage du Chevalier Chardin en persea aux Indes Orientals. Translated by Abbasi I. Tehran: Tose Publication; 1966. p 282-5. [In Persian]

15. Polak JE. Persien das land und seine bewohner. Translated by Jahandar K. Tehran: Kharazmi Publication; 1989. p 435. [In Persian]

16. Bastani Parizi E. In garlic and onions. Tehran: Elm Publication; 1988. p 201. [In Persian]

17. Cliff JDRT. Syphilis or Most Unfortunate History of Incident. Translated by Ohadi (Yekta) M. Tehran: Language and Literature (Vahid); 1969. p 74. [In Persian]

18. Golshani SA. Baha'al-Dawlah Razi (860-912 AH), the Innovator Surgeon, Empiricist Physician and Pioneer in Immunology. Res Hist Med. 2012;1(4):185-90. [In Persian]

19. Chardin J. Journal du voyage du Chevalier Chardin en persea aux Indes Orientals. Translated by Yaghmaei I. Tehran: Tose Publication; 1993. p 1133. [In Persian]

20. Navai A. Of policy documents and correspondence from the years 1038 to 1105 BC. With detailed notes. Tehran: Iranian Cultural Foundation Publication; 1981. p 4. [In Persian]

21. Al-Hossini Alqvmy Qazi A. Kholasat al-Tawārīk. Researcher and editor by Eshraghi E. Tehran: Tehran University Publication; 2004. p 959. [In Persian 